DOI: http://dx.doi.org/10.20535/0203-377130201573193

Д. М. Зінченко ${ }^{1}$, к.т.н., доиент, Р. Р. Діденко ${ }^{2}$ бакалавр

\title{
АЕРОДИНАМІЧНИЙ ОБРИС НАДУВНИХ НЕСУЧИХ ПОВЕРХОНЬ ЛІТАКА
}

En The current state of the design load-bearing surfaces of filled ram air. A layout of the bearing surface with a rigid front part and fills the incident flow tail. Submitted parametric study of the effect layout parameters on the aerodynamic characteristics of the wing fills, using methods of computational aerodynamics. Based on the analysis of the test results generated by the layout of the recommendations proposed airfoil.

Ru Рассмотрено современное состояние проектирования несущих поверхностей, наполняемых набегающим потоком воздуха. Предложена компоновка несущей поверхности с жесткой лобовой частью и наполняемой набегающим потоком хвостовой частью. Выполнены параметрические исследования влияния на аэродинамические характеристики параметров компоновки наполняемого крыла, на основании анализа результатов испытаний сформированы рекомендации по компоновке предложенной несущей поверхности.

\footnotetext{
${ }^{1}$ Національний технічний університет Украӥни "Київський політехнічний інститут", кафедра приладів і систем керування літальними апаратами

${ }^{2}$ Національний технічний університет Украӥни "Київський політехнічний інститут", факультет авіаційних і космічних систем
} 


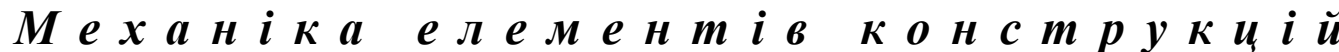

\section{Вступ}

Надзвичайно перспективним напрямком є застосування в конструкції літального апарату несучих поверхонь, що формуються наповненими повітрям об’ємами. Таке рішення дозволяє значно зменшити габарити літального апарату під час транспортування, також $є$ наочною можливість зменшення динамічних навантажень на конструкцію, та, відповідно, зменшення ii ваги. Перший відомий приклад такої конструкції - літак Inflatoplane, спроектований фірмою Goodyear [1]. На сьогодні концепція надувного крила активно досліджується в провідних наукових авіаційних закладах, таких як NACA [2], [3], та в Росії , зокрема в СібНДА [4].

Проте наведені приклади мають один суттєвий конструктивний недолік - порушення герметичності конструкції несучої поверхні призводить до неможливості здійснювати подальший політ. Можливим рішенням зазначених проблем є концепція, покладена в основу конструкції літального апарату Woopy Fly [5] - внутрішні об'єми несучої поверхні негерметичні, але тримають свою форму за рахунок надмірного тиску, що постачається до внутрішніх об'ємів крила через забірники повітря, обладнані вентиляторами. Крім того, в ході льотних випробувань Woopy Fly було отримано надзвичайно важливі з точки зору проектування та експлуатації властивості - неможливість штопору, низький рівень максимального перевантаження конструкції, що дозволяє виконати крило значно легшим за існуючі аналоги, швидке складаннярозкладання, малі об'єми в складеному стані.

\section{Постановка задачі}

Ставиться задача дослідити вплив відносного кроку надувної секції за розмахом та кута закручення кінцевого перетину крила на його аеродинамічні характеристики.

\section{Методика досліджень}

Для визначення впливу параметрів компонування на аеродинамічні характеристики розглянуто крило кінцевого розмаху 3 профілем $N A C A 2412$, який $є$ широко вживаним в конструкції крил літаків загального призначення, зокрема такий профіль застосовується в компонуванні крил літаків фірми Cessna.

Ідеологічно конструкція крила складається 3 2-х частин - жорсткої лобової та м'якої хвостової частини. При цьому лобова жорстка частина сприймає до $80 \%$ аеродинамічного навантаження, а хвостова частина є негерметичною та наповнюється потоком повітря через канали повітря. Зважаючи на наявність експериментально підтверджених ([6] [7]) деформацій кінцевих перетинів, вплив конструктивних особливостей на аеродинамічні характеристики надувних несучих поверхонь необхідно визначити як для прямого крила, так і для крила 3 наявністю крутки перетинів. 
Концептуальна схема об'єкта досліджень - надувної несучої поверхні літака наведена на рис. 1.

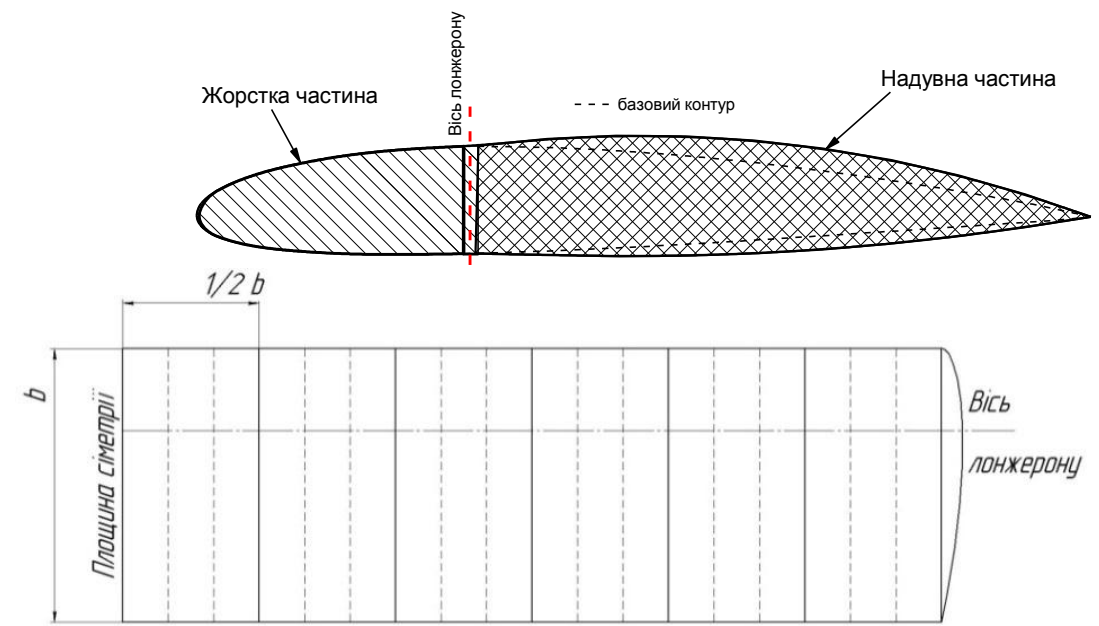

a)

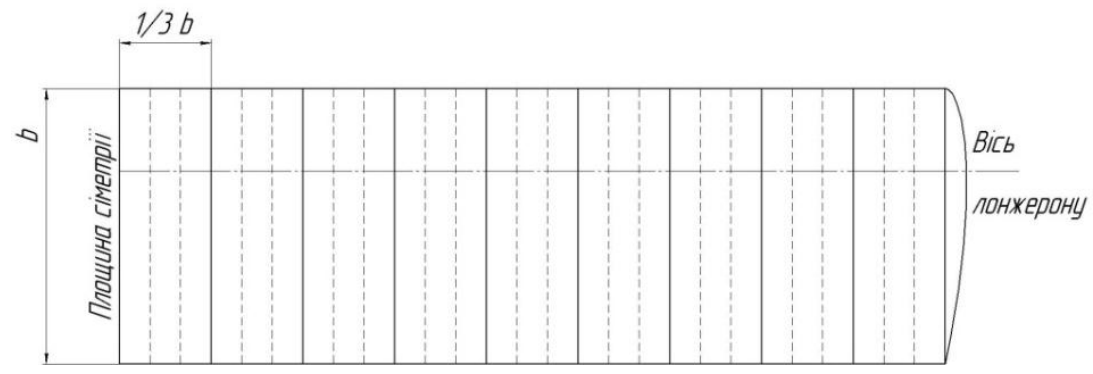

б)

Рис. 1. Концептуальна схема об'єкта досліджень

а - відносний розмах надувної секції 1/2 хорди відсіку;

б - відносний розмах надувної секції $1 / 3$ хорди відсіку

3 урахуванням специфіки роботи надувного крила в якості критеріїв доцільності застосування прийнятих конструкторських рішень прийняті наступні :

Максимальне значення коефіцієнту підіймальної сили Су мах, що визначає мінімальну швидкість польоту $V_{M I N}$, яка згідно норм льотної придатності [8] залежить від швидкості звалювання $V_{S}$ :

$$
V_{S}=\sqrt{\left(\frac{2 * m * g}{\rho * C_{\text {yamax }} * S}\right)}
$$

Значення похідної коефіцієнту підіймальної сили $C y^{\alpha}$, що також згідно норм льотної придатності [8] визначає рівень перевантаження , що діє на конструкцію літака під час польоту в турбулентній атмосфері:

$$
n_{y}=1+A_{V, G / S} * C_{Y}^{\alpha}
$$

де $A_{V, G / S}$ - коефіцієнт, що враховує швидкість польоту літака, навантаження на крило, швидкість вертикального пориву вітру та інші зовніш- 
ні фактори, не пов'язані із аеродинамікою та визначається згідно [8], П. $341(\mathrm{c})$.

Зміна коефіцієнту лобового опору $C$ х в польотному діапазоні значень $C y$, що визначає зміну потрібної тяги та, відповідно - витрату споживаної енергії, згідно [9]:

$$
\mathrm{P}_{\text {ПОТР }}=\frac{G}{K}=G * \frac{C x}{C y} .
$$

Зміна значення похідної $m_{z}^{C_{y}}$, що визначає зміну положення аеродинамічного фокусу крила, та, відповідно, можливі додаткові втрати опору через додаткове відхилення балансуючих поверхонь.

Для визначення впливу особливостей компонування надувних крил на аеродинамічні характеристики застосований панельно-вихровой метод [10], широко вживаний в практиці аеродинамічного проектування. Оскільки, використання будь-якого обчислюваного методу потребує порівняння із результатами фізичного експерименту, то дослідження впливу особливостей поділено на два етапи.

Eman 1. Дослідження аеродинамічних характеристик відсіку прямого крила з профілем NACA 2412 та порівняння отриманих розрахункових результатів із результатами експерименту в аеродинамічній трубі [11]. Геометричні характеристики моделі відсіку крила є аналогічними геометричним характеристикам дослідної моделі та складають: площа крила $S=.096774 \mathrm{~m}^{2} ;$ хорда $b=.127 \mathrm{м} ;$ розмах $l=0.762 \mathrm{м}$.

В якості параметру був прийнятий відносний розмах надувної секції, що дорівнює $1 / 3$ та 1/2 хорди відсіку. Також був розглянутий варіант крила iз зміною кута встановлення перетинів крила по лінійному закону, від $\varepsilon=0$ в кореневому перетині до $\varepsilon=-5^{0}$ в кінцевому перетині. Розрахунок аеродинамічних характеристик виконано для умов проведення експерименту, а саме, швидкість потоку $V=20.6$ м/с; число Рейнольдса $\operatorname{Re}=3.25^{*} 10^{6}$.

Розрахункові моделі відсіку крила, задіяні в розрахунках першого етапу, приведені на рис. 2.

Eman 2. Подальший більш грунтовний аналіз властивостей надувного м'якого крила виконано для крила літака загального призначення 3 відомими аеродинамічними характеристиками. В якості дослідного зразка обраний широковідомий літак Cessna 182, що має крило, сформоване за допомогою дослідженого вище профілю $N A C A$ 2412. Геометричні параметри розрахункових моделей, наведених на рис. 3 є тотожними 3 параметрами крила справжнього літака та складають: площа крила $S=16.3 \mathrm{~m}^{2}$; середня аеродинамічна хорда $b_{C A \mathrm{X}}=1.486 \mathrm{м}$; розмах $l=10.97$ м. Розрахункові моделі крила літака Cessna 182, задіяні в розрахунку, приведені нижче на рис. 3. 


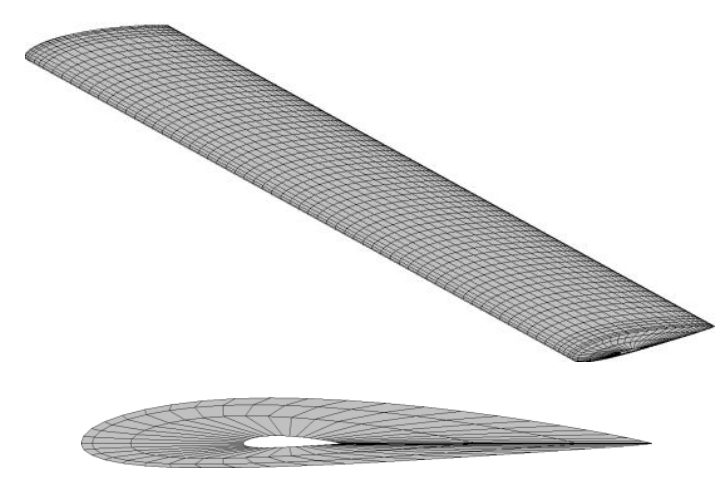

a)

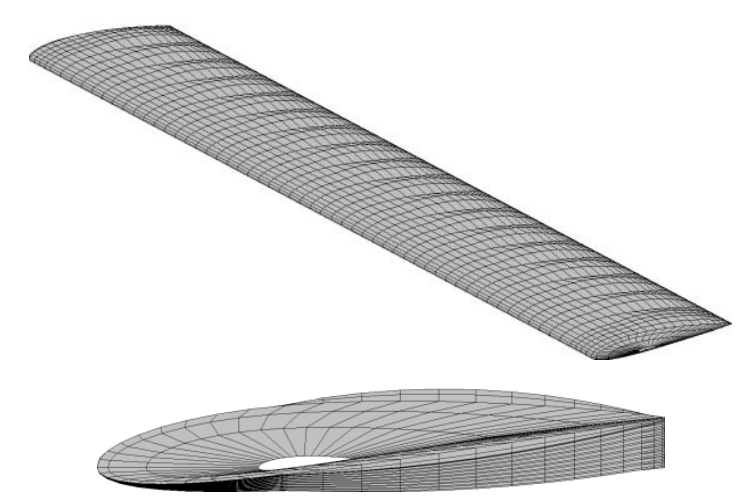

b)

Рис. 2. Розрахункові моделі першого етапу. Відсік крила 3 профілем NACA 2412 $S=.096774 \mathrm{~m}^{2} ; b=.127 \mathrm{м} ; l=0.762 \mathrm{м}$.

$\mathrm{a}$ - базова модель; $\mathrm{b}$ - модель надувного крила 3 круткою $-5^{0}$

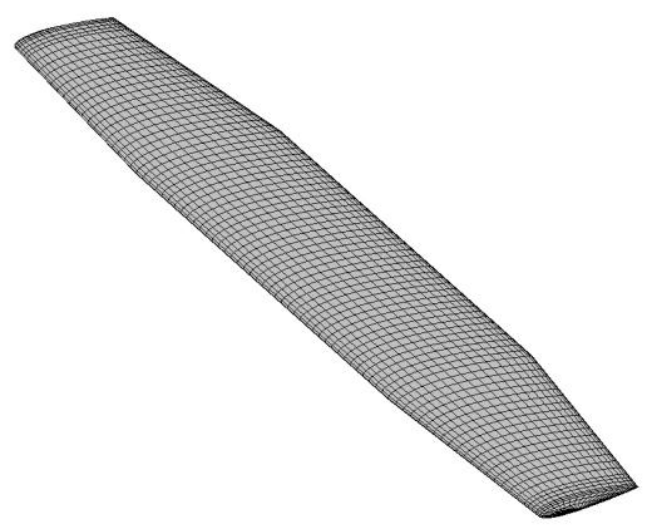

a)

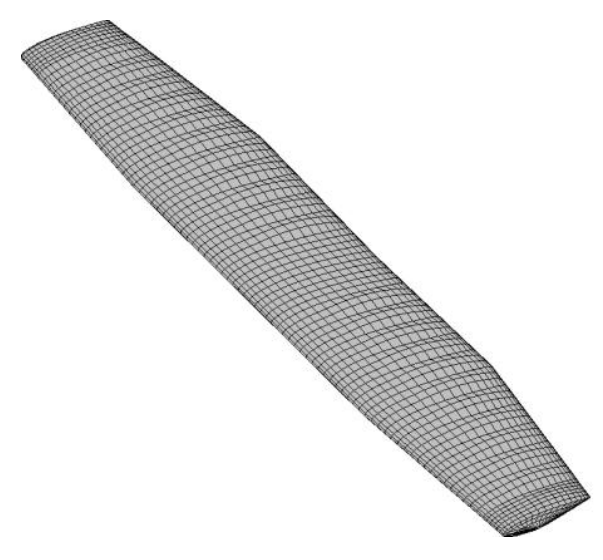

b)

Рис. 3. Розрахункові моделі крила літака Cessna 182 з профілем NACA 2412

$S=16.3 \mathrm{~m}^{2} ; \mathrm{b}_{\mathrm{CAX}}=1.486 \mathrm{M} ; l=10.97 \mathrm{~m}$

$\mathrm{a}$ - базова модель; $\mathrm{b}$ - модель надувного крила 3 круткою $-5^{0}$

\section{Результати розрахунку}

Результати розрахунку першого етапу досліджень моделі прямого відсіку крила 3 профілем NACA 2412 у вигляді залежностей коефіцієнту підіймальної сили від кута атаки $C y=f(\alpha)$, поляри $C y=f(C x)$ та залежностей коефіцієнту повздовжнього моменту від коефіцієнту підіймальної сили $m_{Z}=f(C y)$ подані нижче на рис. 4 - рис. 6 (Порівняння результатів розрахунку та експерименту). 
Механіка елементівконструкцій

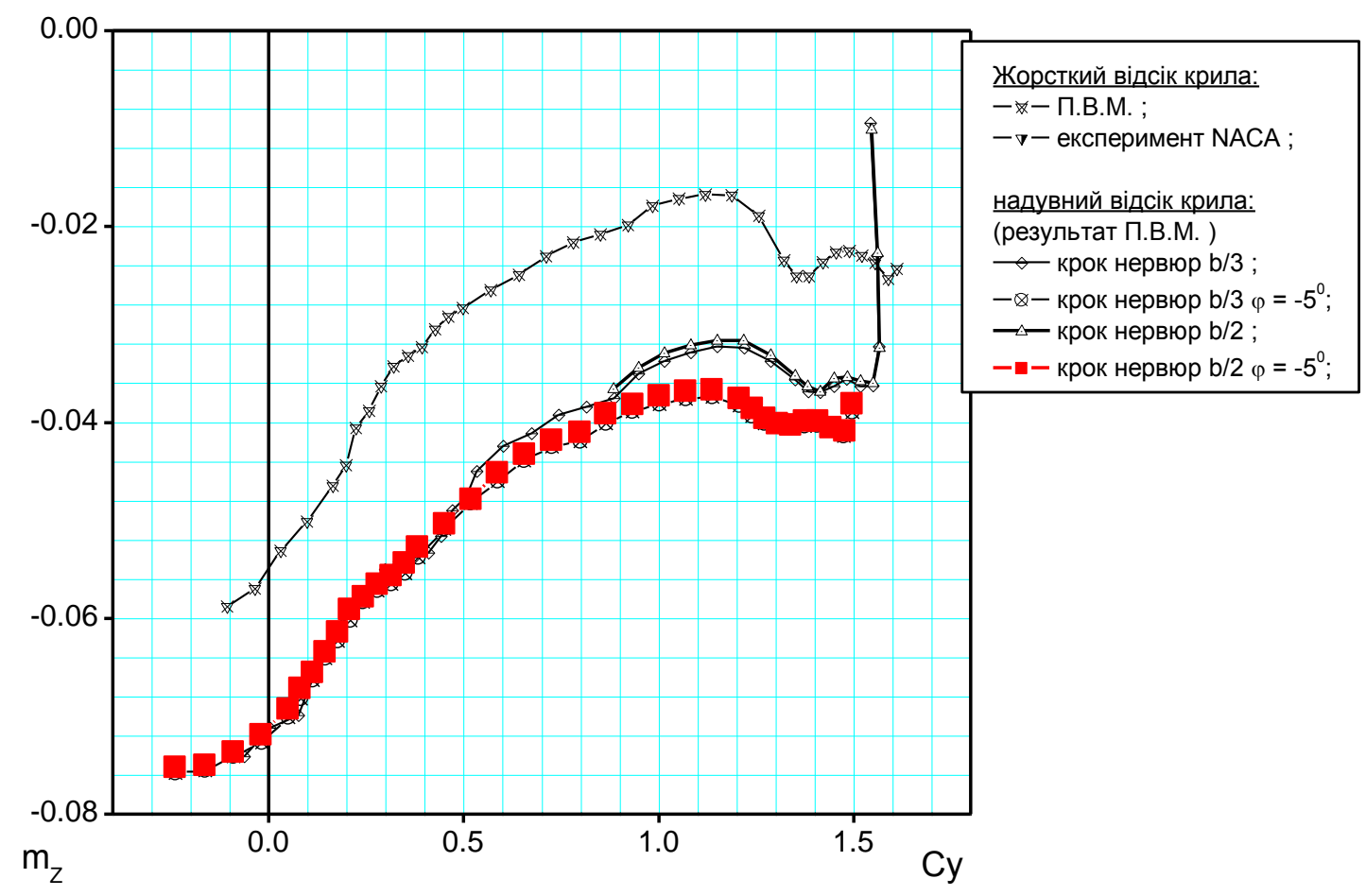

Рис. 4. NACA 2412. Залежність $m_{Z}=f(C y)$. Відсік крила $\lambda=6$, $V=20.6 \mathrm{~m} / \mathrm{c} ; \operatorname{Re}=3.25^{*} 10^{6}$

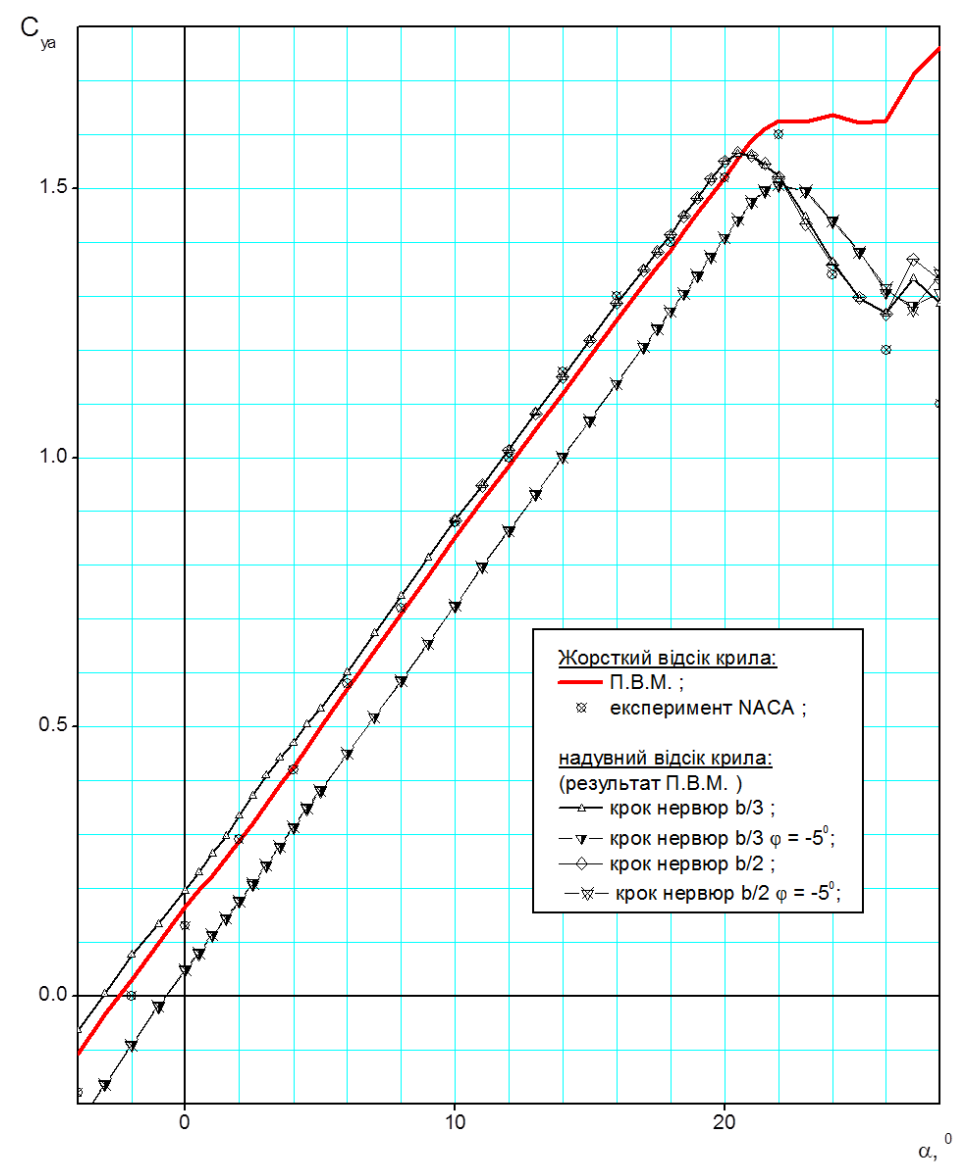

Рис. 5. NACA 2412. Залежність $C y=f(\alpha)$. Відсік крила $\lambda=6$, $V=20.6 \mathrm{M} / \mathrm{c} ; \operatorname{Re}=3.25 * 10^{6}$ 


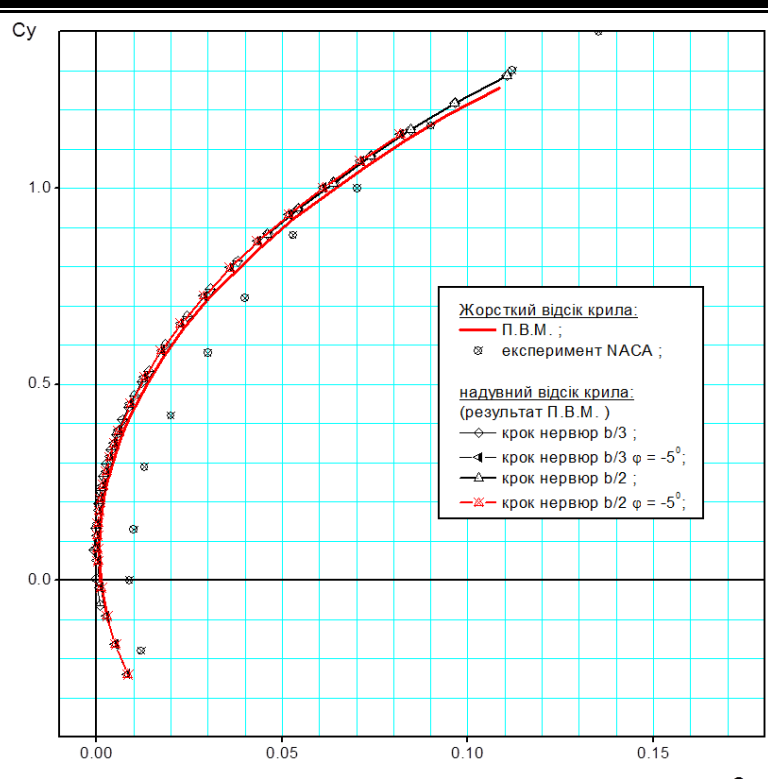

Рис. 6. NACA 2412. Залежність $C y=f(C x)$. Відсік крила $\lambda=6$, $V=20.6 \mathrm{M} / \mathrm{c} ; \operatorname{Re}=3.25 * 10^{6}$

Результати розрахунку другого етапу досліджень моделі крила літака Cessna 182 у вигляді залежностей коефіцієнту підіймальної сили від кута атаки $C y=f(\alpha)$, поляри $C y=f(C x)$ та залежностей коефіцієнту повздовжнього моменту від коефіцієнту підіймальної сили $m_{Z}=f(C y)$ подані нижче на рис. 7 - рис. 9 (Вплив параметрів компонування).

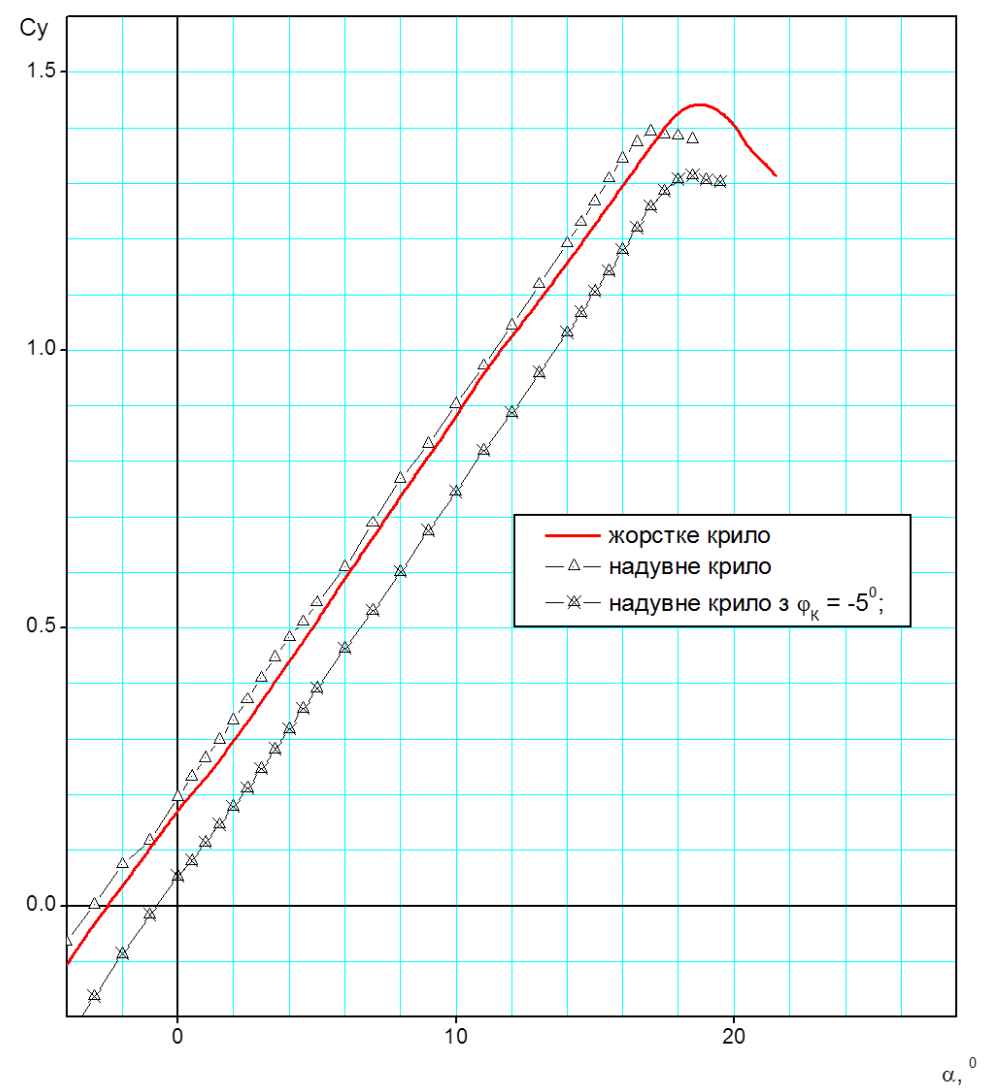

Рис. 7. Крило літака Cessna 182. Залежність $C y=f(\alpha)$. $V=20.6 \mathrm{M} / \mathrm{c} ; \operatorname{Re}=3.25^{*} 10^{6}$ 
Cy

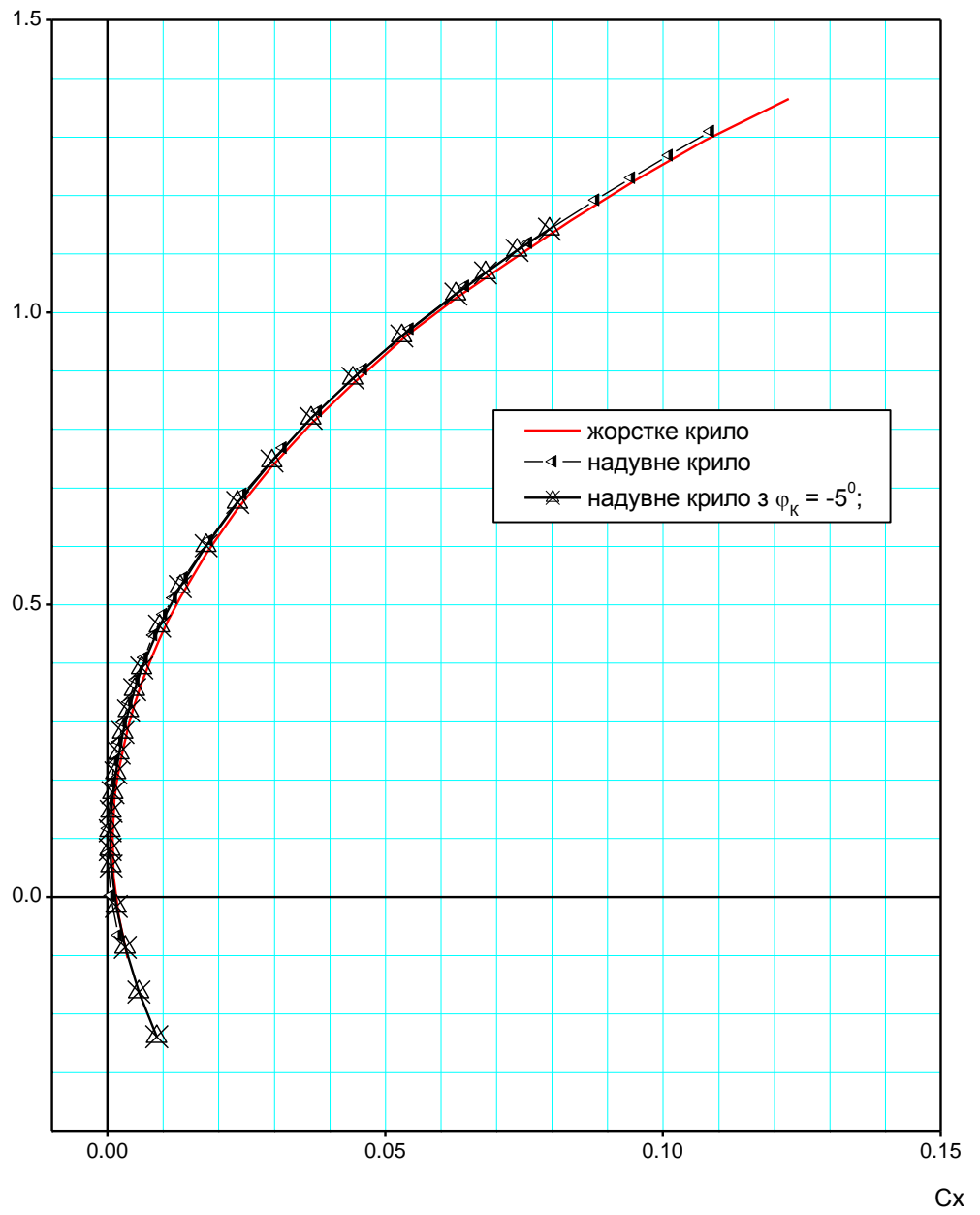

Рис. 8. Крило літака Cessna 182. Залежність $C y=f(C x)$. $V=20.6 \mathrm{~m} / \mathrm{c} ; \operatorname{Re}=3.25^{*} 10^{6}$

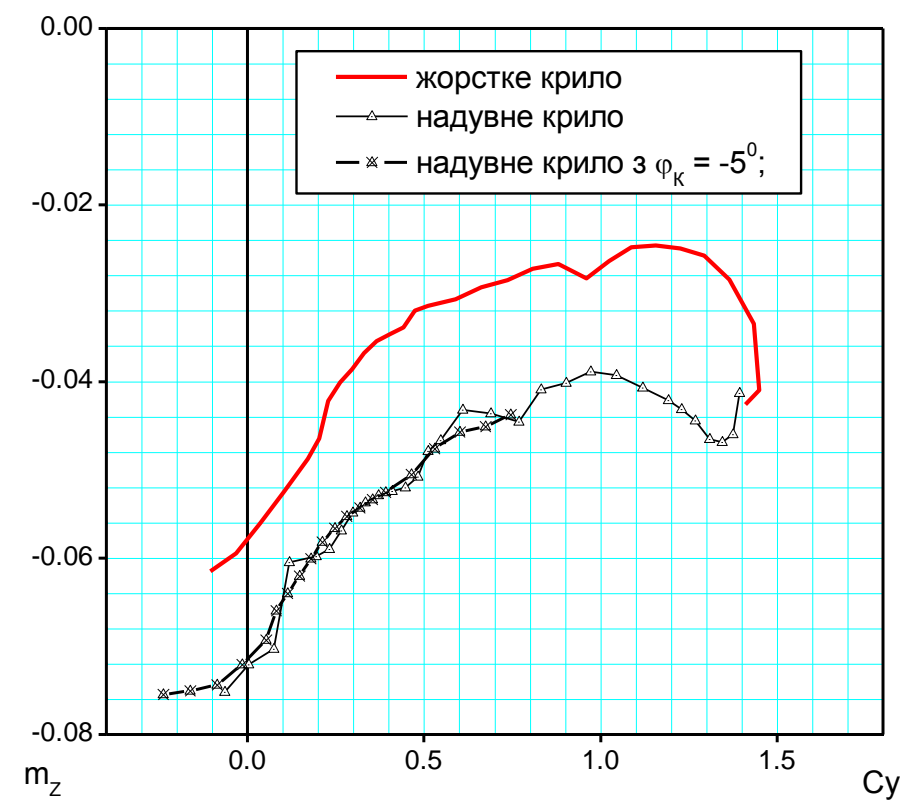

Рис. 9. Крило літака Cessna 182. Залежність $m_{Z}=f(C y)$. $V=20.6 \mathrm{M} / \mathrm{c} ; \operatorname{Re}=3.25^{*} 10^{6}$ 
Наведені на рис. 7 - рис. 9 аеродинамічні характеристики досліджень моделі крила літака Cessna 182 наочно демонструють ті ж самі особливості впливу конструктивних елементів надувного крила, що були виявлені в процесі розрахункових досліджень відсіку крила з профілем, наведених на рис. 4 -рис. 6.

\section{Висновки}

Аналіз аеродинамічних характеристик надувної несучої поверхні літака дозволяє зробити наступні висновки:

Значення похідної $C_{y}^{\alpha}$, що визначає зріст аеродинамічного навантаження на крило при виконанні маневрів в експлуатаційному діапазоні кутів атаки лишається незмінним для розрахункових моделей з кроком надувних секцій від $1 / 2$ до 1/3 місцевої хорди крила, рівень навантажень на конструкцію та ії загальна міцність лишається незмінною;

Залежність коефіцієнту повздовжнього моменту від коефіцієнту підіймальної сили $m_{Z}=f(C y)$, демонструє тотожність характеристик стійкості для розрахункових моделей 3 кроком надувних секцій від 1/2 до 1/3 місцевої хорди крила, а саме значення похідної $m_{Z}^{C y}$, що робить можливим застосування прийнятих методик для проектування оперення нового літака 3 надувним крилом, або ж збереження існуючого оперення на конкретно обраному типі літака в разі його модифікації.

Наявність в конструкції крила відсіків, що надуваються повітрям, незначно зменшує максимальну підіймальну силу, але характер втрати несучих властивостей на кутах атаки, більших за критичний, практично збігається 3 експериментальними даними, отриманими для жорсткого відсіку крила в $N A C A$.

Встановлено, що відносний крок за розмахом надувних секцій крила повинен знаходитись в межах від 1/2 до 1/3 місцевої хорди крила. Зменшення цього параметру призведе як до ускладнення та збільшення ваги конструкції крила, так і до зросту лобового опору.

Модифікація конструкції вже існуючих літаків шляхом встановлення несучої поверхні, що надувається потоком повітря не потребуватиме встановлення більш потужного двигуна та інших грунтовних переробок конструкції через тотожність поляр, наведених на рис. 5.

\section{Список використаної літератури}

1. http://en.wikipedia.org/wiki/Goodyear_Inflatoplane

2. Simpson, A. D., et. al., "BIG BLUE: A High-Altitude UAV Demonstrator of Mars Airplane Technology," IEEE Aerospace Conference, Big Sky, MT, March 6-10, 2005. 
3. Simpson A., Jacob J. D., S. W. Smith, O. Rawashdeh, J. E. Lumpp and W. T. Smith, "BIG BLUE II: Mars Aircraft Prototype with InflatableRigidizable Wings" AIAA- 2005-0813, AIAA Aerospace Sciences Meeting, Reno, NV, Jan 10-13, 2005.

4. Зверьков И. Д. Изучение свойств крыла с волнистой поверхностью и его применение для создания нових образцов малоразмерных летательных аппаратов. Диссертация на соискание ученой степени доктора технических наук. Новосибирск, 2013.

5. http://fly.woopyjump.com/index.php/fr/definition-du-woopy-fly.html

6. Исследование аэродинамических характеристик гибридного крыла // Ортамевзи Гюркан, Дмитрий Николаевич Зинченко// Механіка гіроскопічних систем. - 2014. - №28. - С. 117-125.

7. «Wing with Soft Skin: Effectiveness and Assesment» Universal Journal of Aerodynamics 3 (2015), 34-40 www.papersciences.com

8. Авиационные Правила-23 -Нормы летной годности гражданских легких самолетов -1993 г.

9. Удариев Е. П., Переверзев М. А., Ищзенко С. А. Эксплуатационная аэродинамика. Траекторные задачи. Издательство НАУ. Киев.1998 г.

10. Глушков Н.Н., Инешин Ю.Л., Свириденко Ю.Н. "Применение метода симметричных особенностей для расчета обтекания дозвуковых летательных аппаратов", Ученые записки ЦАГИ, т.ХХ, N1, 1989 г. 18 с.

11. Кравец А. С. Характеристики авиационных профилей. М. 1939 г. 